\title{
IMPACT OF PUBLIC EDUCATION EXPENDITURE ON HUMAN CAPITAL DEVELOPMENT IN NIGERIA (1970-2015)
}

\author{
${ }^{1}$ A. A. Bello $(\mathrm{PhD}),{ }^{2}$ Tijjani Adam Waziri, \\ ${ }^{3}$ Prof Hussainatu Abdullahi (Mrs), ${ }^{4}$ Eziamaka, E. Obi (Mrs) \\ ${ }^{1}$ Department of Economics, Usmanu Danfodiyo University, Sokoto, Nigeria. \\ ${ }^{2}$ Kashim Ibrahim College of Education, Maiduguri, Borno State, Nigeria \\ ${ }^{3}$ Department of Economics, Usmanu Danfodiyo University, Sokoto, Nigeria \\ ${ }^{4}$ MPhil Research Student, Department of Business Administration, \\ Usmanu Danfodiyo University, Sokoto
}

DOI: 10.46609/IJSSER.2020.v05i05.003 URL:https://doi.org/10.46609/IJSSER.2020.v05i05.003

\begin{abstract}
The study empirically examines the impact of public education expenditure on Human Capital Development in Nigeria within a time frame of 46 years (1970-2015). Time-series data sourced from Central Bank of Nigeria and World Development Indices were used and analyzed using Auto Regressive Distributed Lag Model (ARDL) Approach. The results from the Unit Root tests indicate mixture of integration among the variables. ARDL co-integration Bound test suggests the presence of long-run relationship among all the variables. The results estimate on ARDL long-run estimate reveal that Enrolment (ENROL) Proxy for Human Capital Development is positively related to Government Capital Expenditure on Education (GCEE) in which a $1 \%$ change in GCEE leads to $0.02 \%$ change in Enrolment. While ENROL is negatively related to Government Recurrent Expenditure on Education (GREE) that is, 1\% change in GREE will lead to $0.07 \%$ change in ENROL. The study also reveals a unidirectional causal relationship between GCEE and ENROL, and bidirectional relationship between Government recurrent expenditure on ICT (GREICT) and ENROL. The study recommends that careful scrutiny of public expenditures should be undertaken by making Education for all a priority through increased spending since adequate funding is necessary for operations and maintenance of education infrastructures.
\end{abstract}

Keywords: Public Education; Expenditure; Human Capital Development. 


\section{International Journal of Social Science and Economic Research}

ISSN: $2455-8834$

Volume: 05, Issue: 05 "May 2020"

\subsection{INTRODUCTION}

Human Capital Development is considered as a major factor of development in all countries of the world (Becker, 1964). Standard education is a major way of enhancing the quality of human resources. One of the challenges confronting any modern economy is the achievement of sustainable economic growth and development with the ultimate objective of improving the welfare of its citizens. The future of the society depends largely on the quality of its citizen's education because education is the main instrument used by the society to preserve, maintain and upgrade its human capital resource. The education system is undeniably the major backbone of the development of any country as it inculcates in the individual, the ability to be a vital part in nation building (Fafunwa, 1974).

Public spending on education and training is not an end in itself. The goal of investment in public education is to create the skills and attitudes needed for higher levels of productivity and growth. Whether or not such growth will be achieved will depend not only on the amount of resources invested but also on the effectiveness with which the inputs are managed (Adubi and Abioma, 1999). The body vested with the power of the allocation of resources in Nigeria is the Revenue Mobilization, Allocation and Fiscal Commission (RMAFC). Resource allocation to the education sector in Nigeria is achieved through annual budgets. Budgetary allocation to the education sector is channeled through appropriate organs of government and such funds are in turn disbursed to all the levels of education (Oriakhi and Ameh, 2014).

One of the objectives of the Millennium Development Goals (MDGs) is to eradicate illiteracy, while the fourth item on the Seven Point Agenda of the Late President Yar'adua's government was Human Capital Development (Education and Health). Strengthening human capital development according to the plan can be achieved by embarking on a comprehensive reform of tertiary institutions, sustain increased funding of primary and secondary levels of education, sustain increased funding for provision of basic health services and resolve dysfunctional education system.

Health comes next to education in the development of human resources. According to Ogbu and Gallager (1991), a good health policy is a means by which government can at once ensure that manpower is generated in the right mix, distributed in accordance with national priorities and ensure the highest level of labour productivity. Health improvement influences morbidity and labour force productivity thereby, enhancing the process and speeding of economic development.

The study is concentrated on trend analysis which is not appropriate enough in drawing useful conclusion. This is because, when you try to describe large set of data with single indicator you may end up distorting the original data or losing the important detail. Further more, Jibril (2011) 
International Journal of Social Science and Economic Research

ISSN: $2455-8834$

Volume: 05, Issue: 05 "May 2020"

used descriptive statistics, while other studies such as Obi, Ekesiobi, Dimnwobi, and Mgbemena (2016) and Adawo, (2014) used OLS. Rigorous statistical techniques and diagnostic test are used in this study to examine the trend of the variables used in the model along with advanced tool of ARDL model.

\subsection{LITERATURE REVIEW AND THEORETICAL FRAMEWORK}

\subsection{Conceptual Framework}

\subsubsection{Concept of Human Capital}

Economically, capital is referred to as those factors of production used to create goods or services that are not themselves significantly consumed in the production process (UNDP, 2001). In the 1950's, it was discovered that investment in human capital was the primary way to raise individuals' wages making it more effective when compared to other production inputs such as land, financial capital, and labour (Woodhall, 2001). Human capital as a concept can be traced to the Classical School of Thought in 1776, then as a scientific theory by Fitzsimons (1999). Schultz (1961) recognizes human capital as one of the important factors that determine economic growth. He referred to the term human capital as the stock of productive knowledge and skills possessed by workers. Human capital can be categorized by 'something akin to property' that is, knowledge and skills embedded in an individual (Beach, 2009). (Rastogi, 2002) conceptualizes the human capital as knowledge, competency, attitude and behavior embedded in an individual. Human capital has also been categorized as important in itself and also important in the accumulation process.

\subsubsection{Determinants of Human Capital Development}

The determinants of Human Capital Development can be itemized thus;

(i). Population Size: According to Fujita, Kruman and Venebles (1999) and Krugman

(1996), higher densities of population can be associated with higher intensity of economic activities through agglomeration economies. Glaeser and Gottlieb (2009) opine that density boosts productivity due to agglomeration economies and proposes a few reasons why agglomeration economies can exist. These are reduced transportation costs for goods, reduced transportation costs for people and an easier transmission of ideas. Qian and Stough (2012) assert that in regions that have a higher population density, there is an easier access to other individuals. As a result, there is a higher opportunity for face-to face communication which is the main channel through which knowledge can spill over leading to increases in human capital. 
International Journal of Social Science and Economic Research

ISSN: $2455-8834$

Volume: 05, Issue: 05 "May 2020"

(ii). Expenditure: Expenditure on Education has been empirically proven to increase human capital for instance, by Jung and Thorbecke (2003) for the case of Tanzania and Zambia because it influences the distribution of additional human capital stock amidst various household groups through improved labour skills. Idrees and Siddiqi (2013) agree, that "education expenditures are crucial for human capital formation."

(iii). Cultural Diversity and Tolerance: According to Florida (2002b), Mellander and Florida (2006), argue that social diversity signals lower barriers to entry of outside talent with different backgrounds. As a result, regions with higher levels of social diversity may be more attractive to talented individuals with higher levels of human capital while Florida, Mellander and Stolarick, (2007) furthermore observe that tolerance is one of the three important magnets for creative people, since it represents a multicultural society that is open to minorities and therefore provides opportunities for ideological development.

(iv). Urban Amenities / Infrastructures: These are considered as location-specific goods and services directly incorporated into the utility functions of an individual and consist of things such as diversity of consumer goods and services, architecture, recreation areas, public services, scenic views, natural resources, crime rates, and congestion (Glaeser, Kolko and Saiz, 2001).

(v). Industrial Structure: This is found in OECD countries which shows that the more rapid the introduction of knowledge and intensive means of production, such as those based on information technologies, the greater the demand for highly skilled workers (OECD, 1996). Thus, regions with better industry structure should attract people with higher human capital.

(vi). Proximity to Institutions of Higher Education: Abel and Deitz (2011) prove that Universities can influence the growth in local human capital levels by increasing both the supply (Graduates) of and demand (Researchers, Teachers) for highly educated individuals within urban areas. This is both temporarily if they move for a limited time and a land-grant College or University is an institution which has been designated by its State Legislature or Congress to receive the benefits of the Morrill Acts of 1862 and 1890.

\subsubsection{Measurement Methods of Human Capital}

The conventional standard to measure human capital stock has been largely categorized into three parts: Output; Cost; and Income-based approach. School enrolment rates, scholastic attainments, adult literacy, and average years of schooling are the examples of output-based approach; cost-based approach is based on calculating costs paid for obtaining knowledge; and income-based approach is closely linked to each individual's benefits obtained by education and training investment. Measurement and methods of Human Capital based on OECD approach will be: 
International Journal of Social Science and Economic Research

ISSN: $2455-8834$

Volume: 05, Issue: 05 "May 2020"

(i) Output-Based Approach: According to Barro, 1991; Barro and Lee (1993) output-based approach is for the purpose of analyzing relationship between human capital and economic growth, some Economists attempted to measure the stock of human capital utilizing 'school enrollment rates' as a proxy of human capital. Calculating the ratio between individuals of school age and students enrolling in the educational institutions, the Economists show the stock of human capital that each country holds. However, the method includes a drawback that a student's effectiveness can be recognized after participating in production activities. In the perspective of educational attainment, Nehru, Swanson, and Dubey (1993) attempted to measure relationship between human capital and students' 'accumulated years of schooling' in the employable age as educational attainment.

(ii) Cost-Based Approach: This is based on measuring the stock of human capital through summing costs invested for one's human capital. For the purpose of calculating the invested costs, Kendric (1976) utilized an individual's investment costs considering depreciation, and Jorgenson and Fraumeni (1989) presented discounted income in the future. Considering that this approach is based on indirectly measuring stock of human capital, it is difficult to precisely classify boundary between investment and consumption in the perspective of costs for the human capital.

(iii) Income -Based Approach: This is based on the returns which an individual obtains from a labor market throughout education investment. Mulligan and Sala-i-Martin (1995) defines that aggregate human capital is the sum of quality adjustment of each individual's labor force, and presents the stock of human capital utilizing an individual's income. Considering 'human-unrelated factors' which can influence an individual's income, this approach rarely presents a complete measurement for human capital.

\subsection{Concept of Human Capital Development}

Human capital development involves processes that relate to training, education and other inventions in order to increase the level of knowledge, skills, abilities, values and social assets of an employee which will lead to the employee satisfaction performance and eventually on a Firm performance. According to Sullivan and Steven (2003), human capital development is about recruiting, supporting and investing in people through education, training, mentoring, coaching, internship, organizational development and human resource management.

Healthfield (2011) defines human capital development as the framework for helping employees develop their personal and organizational skills, knowledge and ability. According to her, human capital development include such opportunities as employee training, employee career development performance management and development, coaching, mentoring, succession 


\section{International Journal of Social Science and Economic Research}

ISSN: $2455-8834$

Volume: 05, Issue: 05 "May 2020"

planning, key employee, identification, tuition assistance and organizational development. Human capital development could be defined as any activity that aimed at accumulating and utilizing a population that possess adequate educational skills and training necessary for moving the economy forward (Johnson, 2011).

Similarly, Ogujiuba (2013) buttress that human capital development is a process by which government invest fund in the area of education, health, workers welfare and provision of job opportunities in order to make sure that citizens are literate enough to manage other factors of production to ensure increase in the general level of output in the economy.

\subsection{Concept of Public Expenditure}

Public expenditure refers to expenses accrued to government for its maintenance, sustaining the society and the economy at large and for helping other countries. Anyanwuocha (1998) defines public expenditure as the financing of government activities. It deals with the financial operation of the government, the financial development of the State and the corresponding activities of the government. Black (2003) views public expenditure as spending by government at any level, i.e., spending on real goods and services; spending on employment in State services such as administration, defense and education; spending on transfer payments to pensioners, the unemployed and disabled; spending on subsidies and grants to industries; and payment of debt interest. However, public expenditure can be categorized into three forms namely Capital, Revenue and Recurrent expenditures. Capital expenditure is the money invested by a company in acquiring, maintaining, or improving fixed assets such as property, buildings, factories, equipment, and technology (Oyeleke; Raheem and Folade, 2016). Revenue expenditure is a cost that is charged to expense as soon as the cost is incurred. By doing so, a business is using the matching principle to link the expense incurred to revenues generated in the same reporting period. This yields the most accurate income statement results. This includes among others, rent expenses, utility expenses, salary expenses, insurance expenses, commission expenses, manufacturing expenses, legal expenses, postage and printing expenses, etc (Ozoengbe; 2013).

\subsection{Theoretical Framework}

This deals with theories and literature that link public expenditure with human capital development. Most prominent theories are Bowen's Model of public expenditure, Wagner's law of increasing public expenditure, Peacock and Wiseman theory of public expenditure as well as the theory of expenditure limitation.

Bowen (1943) opines that social goods are consumed by all individuals in a community, each of them needs to contribute for the social goods. As he rightly pointed out, we must in the case of public goods add different individuals' curves vertically. Thus, the government will produce an 


\section{International Journal of Social Science and Economic Research}

ISSN: $2455-8834$

Volume: 05, Issue: 05 "May 2020"

amount of social goods equal to the marginal cost of supplying that good, to be equal to the marginal utilities received by the community (Okeke, 2014). Wagner's Law is named after the German Political Economist Adolph Wagner (1835-1917), who developed a "Law of Increasing State Activity" after empirical analysis on Western Europe at the end of the 19th century. The law states that there are inherent tendencies for the activities of different layers of governments to increase both intensively and extensively. It assumes the existence of an economy and the growth of the government activities in which the government sector grows faster than the economy (Edame and Eturoma, 2014).

In 1961, Peacock and Wiseman elicited salient shift of light about the nature of increase in public expenditure based on their study of public expenditure in England (Okeke, 2014). Peacock and Wiseman (1967) suggested that the growth in public expenditure does not occur in the same way that Wagner theorized. They choose the political propositions instead of the organic state where it is deemed that government like to spend money, people do not like increasing taxation and the population voting for ever-increasing social services. This theory deals with the growth of public expenditure. It emphasizes the recurrence of abnormal structures which cause sizable dumps in public expenditure and revenue. Public expenditure should not be expected to increase in a smooth and continuous manner, but in jerks or a stop like fashion to accommodate special needs, such as natural disaster, war epidemics, etc (Edeme and Eturoma, 2014).The Theory of Expenditure Limitation was propounded by AoronWildavsky (2003) which is not about why government should choose to limit spending, the problem of expenditure limitation exists only when there is a public will but not yet a public way to hold down spending. The desire to limit spending, of course does not necessarily mean that citizens or government dislike all or most or even any individual items of expenditure.

\subsubsection{Wagners's Law Of Increasing Expenditure:}

This research work is underpinned to the Wagner's Law of Increasing Expenditure. The law states that there are tendencies for the activities of different layers of government to increase.

Although Wagner's writings had been well known among German Economists, it was not until the 1950's when they reached their English speaking counterparts in the form of "Classics in the Theory of Public Finance" (1958) compiled by Musgrave and Peacock.

The most explicit form of this law, interpreted from the economic-political point of view, expresses the absolute and also relative, extension of the public organization structure alongside and even partially replacing the private organization within the public economy.

Wagner presents three reasons for increasing state participation in the economy: 


\section{International Journal of Social Science and Economic Research}

ISSN: $2455-8834$

Volume: 05, Issue: 05 "May 2020"

(a) Greater complexity of legal relationships and communications, increased urbanization and population density, substitution of portion of private activity for public services.

(b) Greater demand for education, leisure, a more equal distribution of revenue and public services.

(c) State neutralization of private monopolies by the state itself.

\subsection{Empirical Review}

A number of empirical studies have investigated the impact of public expenditure on education. For instance, Okeke (2014) investigated the impact of public health and education expenditure on their sectoral outcome using Time Series annual data. Less than under five (5) mortality rate and total school enrolment were used as health and education outcome respectively. The study used Vector Error Correction Mechanism (VECM) to conduct the study in the period between 1980 and 2010. The result suggest that government health expenditure significantly reduces under 5 mortality rate, while, government expenditure on education did not significantly affect total school enrolment. The study further revealed that additional increase in per capita GDP will increase total school enrolment significantly. The study suggests that education expenditure should be monitored to ensure that funds get to their destination and be better managed so as to impact significantly on education outcome.

Sanusi (2012), conducted a study on the impact of public expenditure on human capital development in Kano State between 1990 and 2009, using annual Time Series data. Recurrent and capital expenditure on education services together with pupils and students gender enrolment, number of teacher/tutors employed, and school building were used as proxies for number of graduates generated in the State as the basis of human capital. The study used both descriptive and empirical (Ordinary Least Square Estimate) statistical analysis to analyze the data. The result of the study showed that there was insufficient funding and inappropriate expenditure in education services, school buildings were inadequate and not in good shape. Public expenditure is statistically significant in building human capital in the study area, implying that there is need to increase budgetary allocation to education. The regression result shows that the value of $\mathrm{R}^{2}$ is 0.8336 which means that about $83 \%$ of the variation in human capital development (Proxied) are explained by government expenditure on education.

Obi, Ekesiobi, Dimnwobi, and Mgbemena (2016), using Time Series data over the period of 1970 to 2013, and by testing stationarity and multi-collinearity of the data, used Ordinary Least Square (OLS) to assess the impact of government education spending and education outcome in Nigeria. The result of the study revealed that, public education spending has a positive and significant effect on education outcome in Nigeria. Public health expenditure and urban 
International Journal of Social Science and Economic Research

ISSN: $2455-8834$

Volume: 05, Issue: 05 "May 2020"

population growth were also found to have positive effects on education outcome but are not significant in determining education outcome. The study recommends among other things, that government should spend more on education, and government should monitor spending given the history of corruption and embezzlement of public funds in Nigeria.

\subsection{METHODOLOGY}

This study utilized Time Series data from secondary source spanning the period 1970 to 2015. The data was drawn from the Statistical Bulletin of the Central Bank of Nigeria of various Issues and the World Bank Data Catalogue. This research work covers a period of 46 years i.e 19702015. This is because Gujarati (2004) emphasized the importance of thirty (30) years time span (i.e. Central Limit Theorem) as more powerful than studies with less than 30 years span period. Nonetheless, the study used non-probability sampling method in the form of availability sampling. The variables in the model consist of both dependent and independent variables as specified below.

(i). Enrolment Rate: Human Capital Development is proxied by Enrolment Rate (ENROL) which is the ratio of total enrolment to the population growth. This is in line with the work of Usman and Anene (2014) and Obi, Ekesiobi, Dimnwobi and Mgbemera (2016).

(ii). The Capital Expenditure on Education: This is the general government expenditure on educational infrastructures, buildings and other productive assets. Usman and Aneneh (2014) used the variable in their studies.

(iii). Re-current Expenditure on Education: This covers general government expenditure on salaries/wages and other regular consumption in the education sector, in line with the work of Ehimare and Okorie, (2014).

(iv). Urban Population Growth: This is measured by the total number of people living in urban areas as defined by National Statistical Office. It is calculated using World Bank population estimates. One of the studies that used this variable as their control variable is the work of Obi, Ekesiobi, Dimnwobi and Mgbemena (2016). As noted earlier, this study used secondary data source (Time Series data) from Nigeria covering the period of 1970-2015 (46 years). Time series macroeconomic data are notably not stationary due to change in their time trend. This study administered the Unit Root test to take quality control of heterogeneity problem. The essence is to investigate whether the series used are stationary or not. If the variables are not stationary, we take the difference and where it becomes stationary and integrated of order one (1), cointegration test for the number of co-integrating vectors will be conducted using Johansen (1988) procedure. If there is no evidence of co-integrating vectors, then Causality Test will be 
conducted using Granger Causality Test. Causality Test defines the relationship among variables statistically.

First and for most, it should be noted that all the variables included in the model are stationary. This is to ensure that every variable has a constant mean and variance. This will make prediction of future value sensible. However, if a variable is non-stationary at level value as expected for most macroeconomic variables, the data will be differenced. This study will adopt the model with modification from the works of Usman and Aneneh (2014); Obi, Ekesiobi, Dimnwobi and Mgbemena (2016); and Okafor, Ogbonna and Okeke (2017) to estimate the impact of public expenditure on education and human capital development in Nigeria. The variables, such as Capital expenditure and recurrent expenditure, are adopted from the work of Usman and Anene (2014), while government re-current expenditure on ICT and urban population growth is adopted from the work of Ehimare,Ogaga-Oghene, Obarisiagbon and Okorie (2014). However, the choice of variables is based on the consideration of the economic condition of the country under study (Nigeria). The model is given as:

$E N R L_{t}=\beta_{0}+\beta_{1}+C E E_{t}+\beta_{2}+R E E_{t}+\beta_{3}+R E I C T_{t}+\beta_{4}+U P G_{t}+\mu_{t} \ldots 3.1$

Where:

$\mathrm{ENRL}=$ Enrolment Rate

GCEE $=$ Government Capital Expenditure on Education.

GREE $=$ Government Recurrent Expenditure on Education.

GREICT $=$ Government Recurrent Expenditure on ICT.

URP $=$ Urban Population Growth

$\beta_{0}-\beta_{1}=$ coefficients.

$\mu$ and $t=$ Error term or white noise and time trend over the study period respectively.

Specification of Autoregressive Distributed Lag (Bound Testing) Model

$\Delta E N R L_{t}=\beta_{0} \sum_{i=1}^{m} \beta_{1} E N R L_{t-i}+\sum_{i=1}^{m} \beta_{2} \Delta G R E E_{t-i}+\sum_{i=1}^{m} \beta_{3} \Delta G C E E_{t-i}+\sum_{i=1}^{m} \beta_{4} \Delta G R E I C T_{t-i}+$

$\sum_{i=1}^{m} \beta_{5} \Delta U R P_{t-i}+\alpha_{1} E N R L_{t-1}+\alpha_{2} G R E E_{t-1}+\alpha_{3} G C E E_{t-1}+\alpha_{4} G R E I C T_{t-1}+\alpha_{5} U R P_{t-1}$ 
$+\mu \ldots .3 .2$

Where $\Delta$ is the difference operator, $\boldsymbol{\beta}_{0}$ in each equation is the constant parameter, $\boldsymbol{\beta}_{\boldsymbol{1}}$ to $\boldsymbol{\beta}_{5}$ are the vectors of the coefficients of the first difference lagged values of the variables controlled in models, while $\boldsymbol{\alpha}_{1}$ to $\boldsymbol{\alpha}_{7}$ for each equation represent the coefficients of the level lagged values of variables captured in the models. Although, the ARDL model consist of two parts, the first part of the equations with $\boldsymbol{\beta}_{1}$ to $\boldsymbol{\beta}_{5}$ stand for the short-run dynamics of the models, while the coefficients $\alpha_{1}$ to $\alpha_{5}$ represents the long-run relationship. The null hypothesis of the above models is defined as $\boldsymbol{H}_{0}: \boldsymbol{\alpha}_{1}=\boldsymbol{\alpha}_{2}=\boldsymbol{\alpha}_{3}=\boldsymbol{\alpha}_{4}=\boldsymbol{\alpha}_{5=0}$ which tells us that there is no co-integration (no existence of long-run relationship) among the variables under consideration whereas the alternative hypothesis is defined as $H_{1}: \alpha_{1} \neq \boldsymbol{\alpha}_{2} \neq \boldsymbol{\alpha}_{3} \neq \boldsymbol{\alpha}_{4} \neq \boldsymbol{\alpha}_{5} \neq \boldsymbol{0}$ which signify the existence of cointegration (presence or evidence of long-run relationship) (Pesaran, Shin and Smith, 2001).

\subsection{RESULTS AND DISCUSSIONS}

\subsection{Interpretation of Results.}

Table 4.1: Descriptive Statistics Results.

\begin{tabular}{|l|l|l|l|l|l|}
\hline & LENROL & \multicolumn{1}{|c|}{ LGCEE } & LGREE & LGREICT & LURP \\
\hline Mean & 0.488072 & 11.05335 & 8.382989 & 6.693119 & 2.770460 \\
\hline Minimum & 0.104990 & 8.288107 & 4.789157 & 3.064325 & 2.650534 \\
\hline Maximum & 1.019100 & 14.50538 & 12.87498 & 12.74334 & 2.846890 \\
\hline Std. Dev & 0.273015 & 2.106788 & 3.024531 & 3.106105 & 0.055523 \\
\hline Observation & $\mathbf{4 6}$ & $\mathbf{4 6}$ & $\mathbf{4 6}$ & $\mathbf{4 6}$ & $\mathbf{4 6}$ \\
\hline
\end{tabular}

Source: Authors' Computation using E-views Version 9.

Table 4.1 shows the summary of the data used in estimating the relationship among the variables. The total number of observation used is 46 , representing the period covered by the study. The mean (average rate) of enrolment is 0.488072 , which range from a minimum value of 0.104990 to maximum 1.019100. Mean value of government capital expenditure on education and government re-current expenditure on education are11.05335 and 8.382989 respectively which range from minimum value of $8.288107,4.789157$ to maximum value of $14.50538,12.87498$. Similarly, the mean value of government recurrent expenditure on information and communication technology is 6.693119, which ranges from minimum value of 3.064325 to maximum value of 12.74334 . Also urban population growth has 2.770460 with minimum value of 2.650534 and maximum value of 2.846890. All the variables have positive values; this implies that we have more of increase than decrease in the changes among the variables. Government Recurrent expenditure on ICT has the highest standard deviation (3.106105), which suggests 
International Journal of Social Science and Economic Research

ISSN: $2455-8834$

Volume: 05, Issue: 05 "May 2020"

that, the degree of variability of Government Recurrent expenditure on ICT is higher than that of any other variable in the distribution. However, Urban Population Growth has lower standard deviation (0.055523), which shows that, the dispersion of the data is closer to its mean.

This study investigated the stationarity level of the variables under study in order to ensure that none of the series is beyond integration of order one i.e. I(1). To achieve the forgoing aim, unit root tests were conducted using Augmented Dickey Fuller (ADF) and Phillip-Perron (PP) Tests and the results revealed that none of the series go beyond integration of order one i.e. I(1). The $\mathrm{ADF}$ and PP results showed that government re--current expenditure on education and urban population growth were all stationary at level value i.e. I(0). Whereas enrolment rate, government capital expenditure, and government recurrent expenditure on information technology were stationary at first difference value i.e. I(1). This is because, in absolute term, their actual values are greater than their respective critical values, which indicates that; null hypothesis which says that, the series are not stationary is rejected. The summary of the Unit Root tests are presented in Table 4.2.

Table 4.2: Unit Root Test Result using ADF and PP tests respectively

\begin{tabular}{lcccc}
\multicolumn{2}{c}{ ADF Test } & \multicolumn{3}{c}{ P-P Test } \\
\hline Variables & At Level At $1^{\text {st }}$ Diff & At Level & At $1^{\text {st }}$ Diff & \\
& Value 1(0) & Value 1 $(1)$ & value $1(0)$ & Value 1(10) \\
\hline ENROL & -0.5668 & $-7.4137 * * *$ & -0.0737 & $-8.9442 * * *$ \\
GCEE & 5.0868 & $-6.4249 * * *$ & 4.0394 & $-6.4248 * * *$ \\
GREE & $5.6406 * * *$ & 3.0154 & $7.8339 * * *$ & -4.4893 \\
GREICT & 5.0355 & $-8.9141^{* * *}$ & -1.8379 & $-13.0720 * * *$
\end{tabular}

Source: Authors' Computation using E-views Version 9.

From the result obtained, some of the variables were found to be stationary at a level value 1(0) and others after the first difference 1(1). This is good for the model as it will pave way for the use of ARDL model; co-integration test will be carried out using auto-regressive distributed lag model. When the stationarity level of the variables was examined, we then conduct ARDL test. ARDL test is estimated by conducting co-integration bound test, long-run estimate of ARDL and short-run dynamic estimate of ARDL. The ARDL bound test is conducted using F-statistic to know if the variables are really co-integrated. If they are co-integrating we estimate ARDL cointegration; if they do not co-integrate we resort to find alternate appropriate model. The condition is that F-statistic value should be greater than the upper bound. If it is not, we accept the null hypothesis of no co-integration. 
International Journal of Social Science and Economic Research

ISSN: 2455-8834

Volume: 05, Issue: 05 "May 2020"

Table 4.3: Results of ARDL Co-integration Bound Test Estimation

\begin{tabular}{ccc} 
F-Statistics- & 7.14 & $\mathrm{~K}-4$ \\
\hline Lower Bound I(0) & Upper Bound I(1) & Level of Significance \\
2.20 & 3.09 & $10 \%$ \\
2.56 & 3.49 & $5 \%$ \\
\hline 3.29 & 4.37 & $1 \%$ \\
\hline
\end{tabular}

Source: Authors' Computation using E-Views version 9

Note: $\mathrm{K}=$ no of observation, $\mathrm{I}(0)$ = Lower bound, $\mathrm{I}(1)$ Upper bound

Table 4.3 shows that F-statistic value (7.1425) falls above critical test statistics at 90\%, 95\% and 99\% of the upper bound I(1). This indicates existence of co-integration among all the underlying variables in the model. i.e. ENROL, GCEE, GREE, GREICT and URP. The independent variable is four (4), therefore, $\boldsymbol{K}=4$. However, if the F- statistic falls below the lower bound $\mathrm{I}(0)$, we cannot estimate such relationship because the variables could not maintain equilibrium in the long-run. This satisfies the condition for estimating long-run relationship between the variables..

This has been carried out after knowing the level of co-integration among the variables so as to know the nature of relationship in the long-run between dependent and independent variables.

Table 4.4: Result of Estimated Long run coefficient

\begin{tabular}{lcccc}
\hline \multicolumn{2}{l}{ Dependent Variable: LENROL } & & & \\
Inde. Variables & Coefficient & Std. Error & T- statistics & P-value \\
\hline LGCEE & 0.0264 & 0.0699 & 0.3781 & 0.0747 \\
LGREE & -0.0779 & 0.0892 & -0.8739 & 0.3876 \\
LGREEICT & 0.1499 & 0.0687 & 2.1831 & 0.0353 \\
LURP & -0.0237 & 0.6836 & -0.0347 & 0.9725 \\
\hline
\end{tabular}

Source: Author's Computation using E-views Version 9 (Appendix IV).

Table 4.4: show the results estimated on ARDL which reveal positive relationship between ENROL and GCEE the relationship was found to be statistically significant at $10 \%$ level implying that an increase (decrease) in government capital expenditure on education leads to increase (decrease) in enrolment rate. For instance, a one percentage change in government capital expenditure on education leads to about 0.0226 percentage change in enrolment rate.

More so, it shows insignificance negative relationship between ENROL and GREE, According to the result $1 \%$ increase (decrease) in government recurrent expenditure on education, will lead to $0.0779 \%$ change in enrolment rate in Nigeria. 
International Journal of Social Science and Economic Research

ISSN: $2455-8834$

Volume: 05, Issue: 05 "May 2020"

The coefficient of GRICT 0.1499 is positively related to ENROL the result is statistically significant at 5\%. A $1 \%$ change in government re-current expenditure on information communication technology leads to about $0.1499 \%$ change in enrolment rate at $5 \%$ level of significance.

The result further shows negative insignificant relationship between URP and ENROL.

The error correction model is conducted to detect the short-run association between the dependent variables ENROL and independent variables.

Table 4.5: Short Run Estimation Results of ARDL (ECM)

\begin{tabular}{lcccc}
\hline \multicolumn{2}{l}{ Dependent Variable: LENROL } & & & \\
Inde. Variables & Coefficients & Std. Error & F- statistics & P- value \\
\hline LGCEE & 1.9900 & 5.4000 & -3.6888 & 0.0012 \\
LGREE & -1.0800 & 3.9600 & -2.7273 & 0.0120 \\
LGREICT & 4.0500 & 1.6600 & 2.4396 & 0.0228 \\
LURP & 0.0701 & 0.0258 & 2.71020 & 0.0125 \\
ECM (-1) & -0.3044 & 0.0656 & -4.6386 & 0.0000 \\
\hline$R^{2}=0.83$ Adjusted $R^{2}=0.70$, DW $=2.093$, F - stat $=6.5611(0.0000)$ &
\end{tabular}

Source: Author's Computation using E-views Version 9

Table 4.5 shows the short-run dynamic relationship between Enrolment rate and its explanatory variables was estimated using Error Correction Model (ECM). The error correction model is negative, less than one (-0.3044) and statistically significant at $1 \%$ level.

Government capital expenditure on education is positive (1.9900) and statistically significant at 1\%. This implies that a $1 \%$ increase (decrease) in government capital expenditure will lead to about $1.9900 \%$ decrease (increase) in enrolment rate in Nigeria. There is negative and statistically significant relationship between government recurrent expenditure on education and enrolment rate in Nigeria. A $1 \%$ increase (decrease) in government re-current expenditure on education will lead to -1.0800 increase (decrease) in enrolment rate in Nigeria. Government recurrent expenditure on ICT has positive and statistically significant effect on enrolment rate in the short-run. Finally, urban population growth has a positive and statistically significant relationship with enrolment rate in Nigeria. Furthermore, the co-efficient of determination $\boldsymbol{R}^{2}$, account for 0.83 (83\%) of the variation of ENROL between the study year 1970 to 2015 are explained by the variables controlled in the model, while the remaining $17 \%$ are explained by other variables not captured by the model (not controlled in the model that is, error term). Moreover, the result proves that F- statistic 6.5611 is statistically significant at $1 \%$, meaning that 
International Journal of Social Science and Economic Research

ISSN: 2455-8834

Volume: 05, Issue: 05 "May 2020"

GCEE, GREE, GREICT and URP have joint effect on ENROL. Therefore, the model is adequate to uphold for policy making.

To ensure the adequacy of the ARDL model, post-estimation diagnostic tests for serial correlation (autocorrelation), heteroscdasticity and normality have been conducted and the outcomes are presented in Tables 4.6.

Table 4.6: Serial Correlations, Heteroscedesticity, and Normality Test

\begin{tabular}{lcc}
\hline \multicolumn{1}{c}{ Tests } & $\begin{array}{c}\text { F- stat. } \\
\text { Value }\end{array}$ & Prob. Value \\
\hline Breusch-Godfrey Serial Correlation LM Test & 0.1972 & 0.8225 \\
Breusch-Pagan-Godfrey Heteroskedesticity Test & 1.2055 & 0.3320 \\
Jarque-Bera Normality Test & 1.4116 & 0.4937 \\
\hline
\end{tabular}

Source: Authors' Computation using E-views Version 9

Breusch-Godfrey serial correlation LM test has a p-value of 0.8225 . This indicates that the null hypothesis of no serial correlation is accepted, since F-statistic is not significant even at $10 \%$ level. However, for the Heteroscadasticity test i.e. Breusch-Pagan-Godfrey heteroscadasticity Test. The result did not show any evidence of heteroscadasticity in the ARDL model. In other words, the result shows evidence of homoscadasticity as shown by the insignificant p-value (0.3320) of F-statistic, Jarque-Bera test was also carried out in which the P - Value is 0.4937. Therefore, the null hypotheses is accepted and reject the alternative hypotheses because the $\mathrm{P}$ Value is greater than levels of significance. From the foregoing, we can conclude that the ARDL model is strongly adequate.

To ensure the stability of the equation and parameters under investigation, stability tests were conducted through the use of cumulative sum (CUSUM) of recursive residual and cumulative sum of squares (CUSUMSQ) of recursive residual techniques.

\subsection{Result of the Granger Causality Test}

The main aim of conducting Granger Causality test is to determine the nature and direction of causality between the dependent variable (enrolment rate) and independent variables (government capital expenditure on education, government re-current expenditure on education, government re-current expenditure on information technology and urban population growth). The test result is summarized and presented in Table 4.7. 
International Journal of Social Science and Economic Research

ISSN: 2455-8834

Volume: 05, Issue: 05 "May 2020"

Table 4.7: Result of the Granger Causality Test

\begin{tabular}{llll}
\hline Null Hypotheses & Obs. & F-statistics & P-values \\
\hline LGCEE does not Granger Cause LENROL & 44 & 5.86288 & 0.0059 \\
\hline LENROL does not Granger Cause LGCEE & 44 & 1.38344 & 0.2627 \\
\hline LGREE does not Granger Cause LENROL & 44 & 5.05091 & 0.0112 \\
\hline LENROL does not Granger Cause LGREE & 44 & 1.45187 & 0.2465 \\
\hline LGREICT does not Granger Cause LENROL & 44 & 7.62336 & 0.0016 \\
\hline LENROL does not Granger Cause GREICT & 44 & 2.52051 & 0.0934 \\
\hline LURP does not Granger Cause LENROL & 44 & 0.21224 & 0.8097 \\
\hline LENROL does not Granger Cause LURP & 44 & 5.82489 & 0.0061 \\
\hline
\end{tabular}

Source: Authors' Computation using E-views Version 9.

As presented in Table 4.7, the Granger causality result shows that, causality runs from government capital expenditure on education to enrolment and it is statistically significant at $1 \%$ level, .i.e. there is uni-directional relationship between LGCE and LENROL.

However, the hypothesis that government re-current expenditure on education does not Granger causes enrolment rate could be rejected going by the p-value of 0.0112 . There is bi-directional causality between government re-current expenditure on information technology and enrolment rate. More so, there is a uni-directional causality between urban population growth and enrolment rate.

\subsection{Discussion of Results}

This study empirically investigates the impact of Public Education Expenditure and Human capital Development in Nigeria between 1970 and 2015 using Time Series data. The study employed ADF and PP test for the Unit Root to check for the stationarity of the Time Series data used. The result of the Unit Root test of both Augmented Dickey Fuller (ADF) and Philip and Perron's (PP) test proved that there is mixture of integration order i.e. other variables are stationary at level: I (0) and others become stationary after first differencing: I (1). Therefore, Autoregressive Distributed Lag model become our estimation procedure, being a technique capable of providing consistent estimation when variables are integrated of different order. Granger Causality test is used to determine the nature and direction of causality between the dependent variable and independent variables.

The discussion of results examined how results of this research are in conformity with similar studies previously reviewed or otherwise. 


\section{International Journal of Social Science and Economic Research}

ISSN: $2455-8834$

Volume: 05, Issue: 05 "May 2020"

The estimated results obtained from Autoregressive Distributed Lag model (ARDL) confirmed the presence of co-integration between enrolment rate and its determinants (Government expenditure on education, government capital expenditure on education, government re-current expenditure on ICT and urban population growth). This is in line with the finding of Sanusi (2012); Obi, Ekesiobi, Dimnwobi, and Mgbemena (2016); Usman and Anene (2014); Oriakhi and Ameh (2012) whose findings shows that, there is co-integration among the variables and they have a statistically significant long-run relationship between the variables.

Moreover, the ARDL long-run result reveals a negative and insignificant relationship between government re-current expenditure on education and enrolment rate. This finding is contrary to the findings of Usman and Anene (2014) and Sanusi (2012).

Similarly, government re-current expenditure on information communication technology has positive relationship with enrolment rate. This result contradicts the findings of Ehimare, OgagaOghene, Obarisiagbon and Okorie (2014) which says government re-current expenditure on communication services indicates a non significant negative relationship on the independent variable in the long-run.

Finally, urban population growth has negative and statistically insignificant impact on enrolment rate. This result contradicts the work of Obi, Ekesiobi, Dimnwobi and Mgbemena (2016).

The error correction model is negative, less than one (-0.3044) and statistically significant at $1 \%$ level. Government capital expenditure on education is positive and statistically significant. There is negative and statistically significant relationship between government re-current expenditure on education and enrolment rate in Nigeria. Government re-current expenditure on ICT has positive and statistically significant effect on enrolment rate in the short-run. Finally, urban population growth has a positive and statistically significant relationship with enrolment rate in Nigeria.

The result on causal relationships among the variables are hereby analyzed in relation to the second objective. The result revealed unidirectional causal relationship between government capital expenditure on education and enrolment rate. This result is similar to the findings of Oriakhi and Ameh (2014) whose findings revealed that various variables used granger causes the independent variable in Nigeria.

Moreover, bi-directional causal relationship is observed between government re-current expenditure on ICT and enrolment rate. Uni-directional causal relationship is however, found between urban population growth and enrolment rate. This means that URP granger causes ENROL. This is also explained by the regression result of the work of Gupta and Verhoever (2001). This is also explained by Fujita, Kruman and Venebles (1999); and Krugman (1996) in 


\section{International Journal of Social Science and Economic Research}

ISSN: $2455-8834$

Volume: 05, Issue: 05 "May 2020"

one of the determinants of human capital development which they stress that, higher densities of population can be associated with higher intensity of economic activities and also lead to growing enrolment into schools.

From the above results, the causality test indicated that our second hypotheses H0: if there is no causal relationship between public education expenditure and human capital development in Nigeria was rejected. This is because all variables of interest have causal effect on human capital development in the long-run.

\subsection{SUMMARY AND CONCLUSIONS}

To add value to the existing knowledge, this study empirically investigated the impact of public education expenditure on human capital development in Nigeria using annual Time Series data from 1970 to 2015. The data was sourced from the Statistical Bulletin of the Central Bank of Nigeria (various Issues) and the World Development Index. The analysis was divided into two namely: descriptive and inferential. The descriptive analysis provides summary of the data through the mean, maximum, minimum and standard deviation. The descriptive result reveals that all the variables in the distribution exert positive mean. The results obtained are summarized as follows:

The ARDL Co-integration Bound tests results indicated that all the variables have a long-run relationship. The result of the estimated ARDL long-run co-efficient shows that government capital expenditure on education is positively associated with enrolment rate and it is significant at $10 \%$. Also, government re-current expenditure on education has negative and insignificant relationship with enrolment rate in Nigeria. Similarly, government re-current expenditure on information communication technology has direct relationship with enrolment rate. A $1 \%$ change in government re-current expenditure on information communication technology leads to about $0.1499 \%$ change in enrolment rate at $5 \%$ level of significance. Finally, urban population growth has negative and statistically insignificant impact on enrolment rate.

Error Correction result (short-run) of ARDL shows that, the error correction ECM is negative and less than one (1) and statistically significant at 1\% level. GCEE is positive and statistically significant; and LGREE has negative and statistically significant, while GREICT has positive and statistically significant relationship with ENROL. Finally URP has a positive and significant relationship with ENROL.

From causality result, the study revealed uni-directional causal relationship between GCEE and ENROL. Also there is bi-directional causal relationship between GREICT and ENROL i.e. ENROL granger cause GREICT, GREICT also granger causes ENROL. In addition, unidirectional causality runs from URP to ENROL and also runs from GREICT to GCEE.. Finally, 


\section{International Journal of Social Science and Economic Research}

ISSN: $2455-8834$

Volume: 05, Issue: 05 "May 2020"

Granger causality test supports the causality relation that exist between enrolment and its explanatory variables in the long-run. For diagnostic test, Jarque-Bera test for normality result shows that residual have normal and identical distribution. Breusch-Godfrey serial correlation LM test shows that there is no serial correlation of residual among the variables. Heteroskedasticity test indicated that the model is not heteroskedastic and not serially correlated.

On the basis of the findings revealed above, the following conclusions are hereby drawn:

The results of this study show that public expenditure does not only have positive impact on human capital development in Nigeria but such impact is strong and statistically significant. However, Government re-current expenditure on ICT contributed positively to enrolment rate in both the short-run and long-run. Government capital expenditure on education has positive impact on enrolment rate in the short-run, and also shows a positive and statistically significant impact in the long-run. The policy implication of this study is that greater emphasis in increasing budgetary allocation as well as effective and efficient management of resources should command an important place towards the improvement of quality education, if the public expenditure on education is to contribute to human capital development.

\subsection{Recommendations}

The study recommends that a careful scrutiny of public expenditures should be done by making education for all a priority through increased spending in the context of human capital development in Nigeria. Also, adequate funding is not only very necessary but highly fundamental for operations, maintenance and investment in the education infrastructure since government capital expenditure on education has a positive impact on enrolment rate in the longrun. Education spending policy needs should focus on not only the re-current expenditure but also the capital expenditure..

\section{REFERENCES}

Abel, J. R. and Deitz, R. (2011), "Do Colleges and University Increase their Human Capital?" Federal Reserve Bank of NewYork Staff Report, 401. New York NY: Federal Reserve Bank of New York.

Adawo, B. (2014), "Does Public Expenditure Management Matter for Education Outcome?" Development Southern Africa, 31(4), 535 - 552.

Adubi, A. and Abioma, E. (1999), "Public Expenditure Management in Nigeria"; In Fiscal Planning And Management in Nigeria. Edited by Komolafe, O. S, Jelliian, H. and Hiley. M. Ibadan: NCEMA. 


\section{International Journal of Social Science and Economic Research}

ISSN: $2455-8834$

Volume: 05, Issue: 05 "May 2020"

Anyanwuocha, R. A. (1998), Fundamentals of Economics. Onitsha: African-FEP Publishers ltd.

Aoron, W. (2003), "Controlling Public Expenditure: The Theory of Expenditure Limitation. OECD Journal of Budgetting, 2(4).

Barro, R. J. (1991), "Economic Growth in a Cross-Section of Countries". Quaterly journal of economics, 106, 407-443.

Barro, R. J. and Lee, J. W. (1993), "International Comparisons of Educational Attainment". Journal of monetary economics, 32, 363-394.

Beach, M. (2009), "A Critique of Human Capital Formation in the U.S and the Economic Returns to Sub-Baccalaureate Credentials". Educational Studies: A Journal of the American Educational Studies, 45(1), 24-38.

Becker, G. S. (1964), Human Capital: The Theoretical and Empirical Analysis with Special Reference to Education. Chicago: Univerity of Chicago Press.

Black, J. (2003), Dictionary of Economics. Oxford University Press.

Ebejer, I. and Ulrike, M. (2009), "The Efficiency of Public Expenditure in Malta". Economic Analysis from the European Commission's Directorate General for Economic and Financial Affairs, 6 (2).

Edame, G. E., and Oturama, A. D. (2014), "The Determinants Of Public Expenditures On Education Infratructural Facilities and Economic Growth in Nigeria". Journal of Business Management And Economics, 5(6), 152-161.

Ehimare, A. O.; Ogaga-Oghene, J. o.; Obarisiagbon, E. I. and Okorie, U.C. E. (2014), "The Nigerian Governments Expenditure on Human Capital Development: An Efficiency Analysis". European Journal of Business and Social Sciences, 3(7), 1 - 13. Retrieved 02 26, 2017, from http://www.ejbss.com/recent.aspxy.

Fafunwa, A. B. (1974). History of Education in Nigeria. London: Allen and Unwin Publishers.

Fagerlind, A. and Saha, L. J. (1997), Education and National Development. New Delhi: Education and professional publications.

Fitzsimons, P. (1999), "Human Capital Theory and Education". The Encyclopedia of Education. London: Macmillan. 


\section{International Journal of Social Science and Economic Research}

ISSN: $2455-8834$

Volume: 05, Issue: 05 "May 2020"

Florida , R. (2002b), "The Econmic Geography of Talent". Annals of Association of American Geographers, 92(4), 743-755.

Florida, R. (2002a), The Rise of the Creative Class. New York: Basic books.

Florida,R.(2002c), "Bohemia and Economic Geography". Journal of economic geography, 2, 5571.

Florida, R., Mellander, C. and Stolarick, K. (2007), "Inside the Black Box of Regional Development-Human Capital: The Creative Class and Tolerance. Working Paper Series of Economics and Institutions of Innovation .

Glaeser, E. L. and Gottlieb, J. D. (2009), "The Wealth of Cities: Agglomeration Economies with Spacial Equilibrium in the United States". NBER Working Paper.

Glaeser, E. L., Kolko, J. and Saiz, A. (2001), "Consumer City". Journal of Economic Geography, 1(1), 27-50.

Gujarati, D. N. (2004), Basic Econometrics (Third ed.). USA: Mc Graw-Hill, Inc.

Healthfield, B (2011), Human Capital: A Theoretical and Empirical Analysis with Special Reference to Education Analysis. Chicago: University of Chicago Press

Idrees, A. S., and Siddiqi, M. W. (2013), "Does Public Education Expenditure Causes Economic Growth? Comparison of Developed and Developing Countries". Pakistan Journal of Commerce and Social Science, 7(1), 174-183.

Jibril, B. T. (2011) "The Determinants for Traditional Qur'anic Education System (Almajirci) in Kano State". Paper presented at ABU Zaria. Economics Department, Ahmadu Bello University Zaria.

Jorgenson, D. and Fraumeni, M. B. (1989), The Accumulation of Human and Non-Human Capital (1948-84 ed.). (Lipsey, and Tice, Eds.) Chicago: University of Chicago Press.

Jung, H. S. and Thorbecke, E. (2003), "The Impact of Public Education Expenditure on Human Capital, Growth"; Journal of Policy Modelling, 54(3), 701-725.

Kendric,J.W.(1976), The Formation and Stock of Total Capital. (V. B. Research, Ed.) New York: 
International Journal of Social Science and Economic Research

ISSN: 2455-8834

Volume: 05, Issue: 05 "May 2020"

Mellander, C. and Florida, R. (2006), "Human Capital or the Creative Class:Explaining Regional Development in Sweden". KTH/CESIS Working Paper Series Economics and Institution of Iinnovation.

Mincer, J. (1958), "Investment in Human Capital and Personal Income Distribution". Journal of political economy, 66(4), 281-302.

Mulligan,C.,\&Salai-Martin,X.(1995), "Measuring Aggregate Human Capital". NBER Working Paper.

Nehru, V.; Swanson, E., and Dubey, A. (1993), "A New Data Base on Human Capital Stock Sources, Methology and Result". Working Paper No: 1124.

Obi, C. U.; Ekesiobi, S. C.; Dimnwobi, S. K., and Mgbemena, E. M. (2016), "Government Education Spending and Education Outcome in Nigeria". International Journal of Economics, Finance and Management Sciences, 4(4), 223 - 234. doi:10.11648/j.ijefm.20160404.18.

Odia, L. O. and Omofonwan, S. I. (2007), "Education System In Nigeria: Problems and Prospects". Journal of Social Science, 18-86.

Ogbu, O. and Gallager, M. (1991), "Public Expenditures and Health Care in Africa". School Science and Medicine, 34(6), 15 - 24.

Ogujiuba, K. (2013), "The impact of Human Capital Formation on Economic Growth in Nigeria". J Economics 4(2): 121-132 (2013).

Okafor, C. N.; Ogbonna, K. S. and Okeke, C. I. (2017), "Effect of Government Expenditure on Human Capital Development in Nigeria". IIARD International Journal of Banking and Finance, 3(2), 1-14.

Okeke, B. (2014), Impact of Public Sector Spending on Education and Health Outcome in Nigeria. Nsukka: University of Nigeria Nsukka.

Oriakhi, D. E. and Ameh, G. (2014). "Government Expenditure and The Development of the Education Sector in Nigeria: An Evaluation". Review of Public Administration and Management, 3(5). Retrieved March 2017.

Oyeleke, O. J., Raheem, J. A. and Folade, O. E. (2016), "Government Capital Expenditure and Economic Growth in Nigeria: Any Lesson from Disagregated Fractional Analysis? European Journal of Business and Management, 8(13), 76-84. 
International Journal of Social Science and Economic Research

ISSN: 2455-8834

Volume: 05, Issue: 05 "May 2020"

Ozoengbe, S. A. (2013), "The Relative Impact of Federal Capital and Recurrent Expenditure on Nigeria's Economy". American Journal of Economics, 3(5), 210-221. doi:10.5923/j.economics.20130305.02.

Peacock, A. and Wiseman, J. (1967), The Growth of Public Expenditure in the UK. Princeton, USA: Princeton University Press.

Pessaran, M. H.; Shin, Y. and Smith, R. J. (2001), "Bound Testing Approach to the Analysis of Level Relationships". Journal of Applied Econometrics, 15, 289-326.

Qian, H.; Acs, Z. J. and Stough, R. (2012), "Regional System of Entreprenuearship: The Nexus of Human Capital, Knowledge and New Firm Formation". Journal of Economic Geography.

Rastogi, P. N. (2002), "Knowledge Management and Intellectual Capital as a Paradigm of Value Creation". Human Systems Management, 21(4), 229-240.

Sanusi, A. (2012), "The Impact Of Public Expanditure On Human Capital Development In Kano State"; Unpublished Msc. Thesis, Ahmadu Bello University Zaria.

Schultz, T. W. (1961), "Investment in Human Capital". American Economic Review, 15-17.

UNDP. (2001), Human Development Report: Concept and Measurement of Human Development. New York: Oford University Press.

Usman, O. A. and Anene, E. C. (2014), "Impact of Public Expenditure on Human Capital Development in Nigeria: A Case of Nigerian Tertiary Institution". International Journal in Management and Social Science, 2(3), 17 - 23. Retrieved February 2017

Woodhall, M. (2001), "Human Capital: Educational Aspects". International Encyclopedia of the Social and Behevoral Science.

World Bank. (2007). Report. Washigton DC: World Bank. 